\title{
Druggable Molecular Pathways in Chronic Lymphocytic Leukemia
}

\author{
Mohammad Almasri (D, Marah Amer, Joseph Ghanej (D), Abdurraouf Mokhtar Mahmoud, Gianluca Gaidano * $\mathbb{D}$ \\ and Riccardo Moia
}

Citation: Almasri, M.; Amer, M.; Ghanej, J.; Mahmoud, A.M.; Gaidano, G.; Moia, R. Druggable Molecular Pathways in Chronic Lymphocytic Leukemia. Life 2022, 12, 283. https:// doi.org/10.3390/life12020283

Academic Editor: Katalin Kelemen

Received: 24 December 2021

Accepted: 12 February 2022

Published: 14 February 2022

Publisher's Note: MDPI stays neutral with regard to jurisdictional claims in published maps and institutional affiliations.

Copyright: (C) 2022 by the authors. Licensee MDPI, Basel, Switzerland. This article is an open access article distributed under the terms and conditions of the Creative Commons Attribution (CC BY) license (https:// creativecommons.org/licenses/by/ $4.0 /)$.
Division of Hematology, Department of Translational Medicine, Università del Piemonte Orientale, 28100 Novara, Italy; 20041440@studenti.uniupo.it (M.A.); 20041444@studenti.uniupo.it (M.A.); 20041548@studenti.uniupo.it (J.G.); abdurraouf.mahmoud@uniupo.it (A.M.M.); riccardo.moia@uniupo.it (R.M.) * Correspondence: gianluca.gaidano@med.uniupo.it; Tel.: +39-0321-660-655; Fax: +39-0321-620-421

\begin{abstract}
Chronic lymphocytic leukemia (CLL), the most common type of leukemia in adults, is characterized by a high degree of clinical heterogeneity that is influenced by the disease's molecular complexity. The genes most frequently affected in CLL cluster into specific biological pathways, including B-cell receptor (BCR) signaling, apoptosis, NF- $\mathrm{B}$, and NOTCH1 signaling. BCR signaling and the apoptosis pathway have been exploited to design targeted medicines for CLL therapy. Consistently, molecules that selectively inhibit specific BCR components, namely Bruton tyrosine kinase (BTK) and phosphoinositide 3-kinase (PI3K) as well as inhibitors of BCL2, have revolutionized the therapeutic management of CLL patients. Several BTK inhibitors and PI3K inhibitors with different modes of action are currently used or are in development in advanced stage clinical trials. Moreover, the restoration of apoptosis by the BCL2 inhibitor venetoclax offers meaningful clinical activity with a fixed-duration scheme. Inhibitors of the BCR and of BCL2 are able to overcome the chemorefractoriness associated with high-risk genetic features, including TP53 disruption. Other signaling cascades involved in CLL pathogenesis, in particular NOTCH signaling and NF-kB signaling, already provide biomarkers for a precision medicine approach to CLL and may represent potential druggable targets for the future. The aim of the present review is to discuss the druggable pathways of CLL and to provide the biological background of the high efficacy of targeted biological drugs in CLL.
\end{abstract}

Keywords: chronic lymphocytic leukemia; precision medicine; target therapy

\section{Introduction}

Chronic lymphocytic leukemia (CLL) is the most common type of leukemia in adults. The median age at diagnosis is 72 years, and the male to female ratio is 1.7:1. CLL is characterized by the monoclonal expansion of mature B cells with typical phenotype (CD5+ CD19+ CD20+ CD23+ sIg low) in the peripheral blood, bone marrow, and lymphoid tissues. The development of CLL is often preceded by a non-symptomatic precursor state called monoclonal B-cell lymphocytosis (MBL), defined as a monoclonal B-cell count $<5 \times 10^{9} / \mathrm{L}$ with the typical phenotype of CLL [1].

CLL is characterized by a marked degree of heterogeneity both at the clinical and at the biological level. Some patients have an indolent disease that does not require therapy for many years. Conversely, other patients have an aggressive disease that requires treatment soon after diagnosis and/or may subsequently undergo histologic transformation into an aggressive lymphoma, known as Richter syndrome [2]. The biological heterogeneity of CLL can be ascribed to the immunogenetic origin of the disease, as reflected by immunoglobulin heavy-chain (IGHV) gene status as well as to the profile of genetic alterations of protooncogenes and tumor-suppressor genes that are acquired by each individual patient [2-4].

The mutational status of IGHV genes plays a pivotal role in the biological and clinical profile of CLL. Mutated CLL (M-CLL) displays a rate of somatic hypermutation in the 
IGHV genes higher than $2 \%$ when compared to the corresponding germline IGHV gene counterpart, derived from post-germinal center (GC) B cells, and generally has an indolent disease course [5]. Conversely, unmutated CLL (U-CLL) displays a rate of IGHV gene somatic hypermutation lower than $2 \%$ compared to the corresponding germline IGHV gene counterpart, does not experience the GC reaction, and displays a more aggressive disease course $[6,7]$. B-cell receptor (BCR) signaling plays a fundamental pathogenic role in CLL, as documented by the biased usage of IGHV genes as well as by evidence of the dependence of CLL cell survival and growth upon BCR signaling [8,9]. These notions point to the BCR as a key component in CLL development and progression and as a main druggable pathway for molecular therapy with BCR inhibitors [8].

In addition to the BCR pathway, several molecular studies have identified different genetic lesions that might be used as molecular predictors or therapeutic targets $[3,4,10]$. The genetic landscape of CLL lacks a unifying molecular alteration, is markedly heterogeneous, and includes gross chromosomal aberrations, namely del13q14, trisomy 12, del17p13, and de11q23 as well as mutations of many cancer-related genes. The genes most frequently affected by molecular alterations in CLL cluster into specific biological pathways, including NOTCH1 signaling (NOTCH1 and FBXW7), DNA damage response (ATM, TP53, POT1), apoptosis (miR15/16 and BCL2), BCR and toll-like receptor (TLR) signaling (EGR2, BCOR, MYD88, TLR2, IKZF3), NF- $\mathrm{BB}$ signaling (BIRC3, NFKBIE, TRAF2, TRAF3), and RNA splicing and metabolism (SF3B1, U1, XPO1, DDX3X, RPS15) (Table 1) [9,11,12].

Table 1. Main molecular pathways involved by gene mutations in CLL.

\begin{tabular}{cc}
\hline The Biological Pathways & Mutated Genes \\
\hline NOTCH1 Signaling & NOTCH1, FBXW7 \\
\hline BCR and Toll-like receptor signaling & $E G R 2, B C O R$, MYD88, TLR2, IKZF3 \\
\hline MAPK-ERK pathway & KRAS, NRAS, BRAF, MAP2K1 \\
\hline RNA Splicing and metabolism & $S F 3 B 1$, U1, XPO1, DDX3X, RPS15 \\
\hline NF- $k B$ Signaling & $B I R C 3$, NFKBIE, TRAF2, TRAF3 \\
\hline DNA damage response & ATM, TP53, POT1 \\
\hline Apoptosis & miR15/16, BCL2
\end{tabular}

The continuous improvement in the understanding of CLL pathogenesis has allowed the development of novel therapies that specifically target pivotal signaling pathways of CLL cells. In the present review, we cover the main biological pathways of CLL pathogenesis and the potential vulnerabilities that might be targeted in each pathway. Targeted therapy has already entered the clinical practice of CLL since several years, and its role is continuously expanding. In fact, seminal translational studies have led to understand that CLL genetic features (i.e., IGHV mutational status and TP53 abnormalities) are important biomarkers of refractoriness to chemotherapy and, therefore, act as predictors for treatment choices $[2,4,13,14]$. For example, TP53 disruption and unmutated status of IGHV genes are well-established predictors of chemorefractoriness that mandate treatment with targeted agents (BCR and / or BCL2 inhibitors) that can circumvent, at least in part, the CLL refractoriness to chemo-immunotherapy (CIT). In addition, other gene mutations (i.e., NOTCH1, $B I R C 3)$ are under scrutiny in order to clearly define their prognostic and/or predictive value $[3,10,15-17]$.

\section{Targeting the BCR in CLL}

The BCR consists of a membrane immunoglobulin non-covalently bound to a heterodimer composed of $C D 79 \alpha(\operatorname{Ig} \alpha)$ and $C D 79 \beta(\operatorname{Ig} \beta)$. In normal B cells, antigen binding to the BCR triggers the downstream signaling cascade, thus inducing cell proliferation, survival, and differentiation stimuli (Figure 1) $[18,19]$. Compared to normal B cells, the BCR of many CLL cells is characterized by an intrinsically higher reactivity to antigens $[20,21]$. 
Moreover, in some cases, the BCR of CLL cells may also interact with a BCR expressed on other CLL cells, thus auto-enhancing BCR signaling [21,22]. About one-third of patients with CLL carry quasi-identical BCR sequences that can be classified into stereotyped BCR subsets based on the structure of their complementarity-determining regions (CDRs) [23,24]. Approximately 200 different CLL stereotyped BCR subsets have been identified to date [23]. These findings reinforce the notion that specific antigenic stimuli triggering the BCR may be involved in CLL pathogenesis.

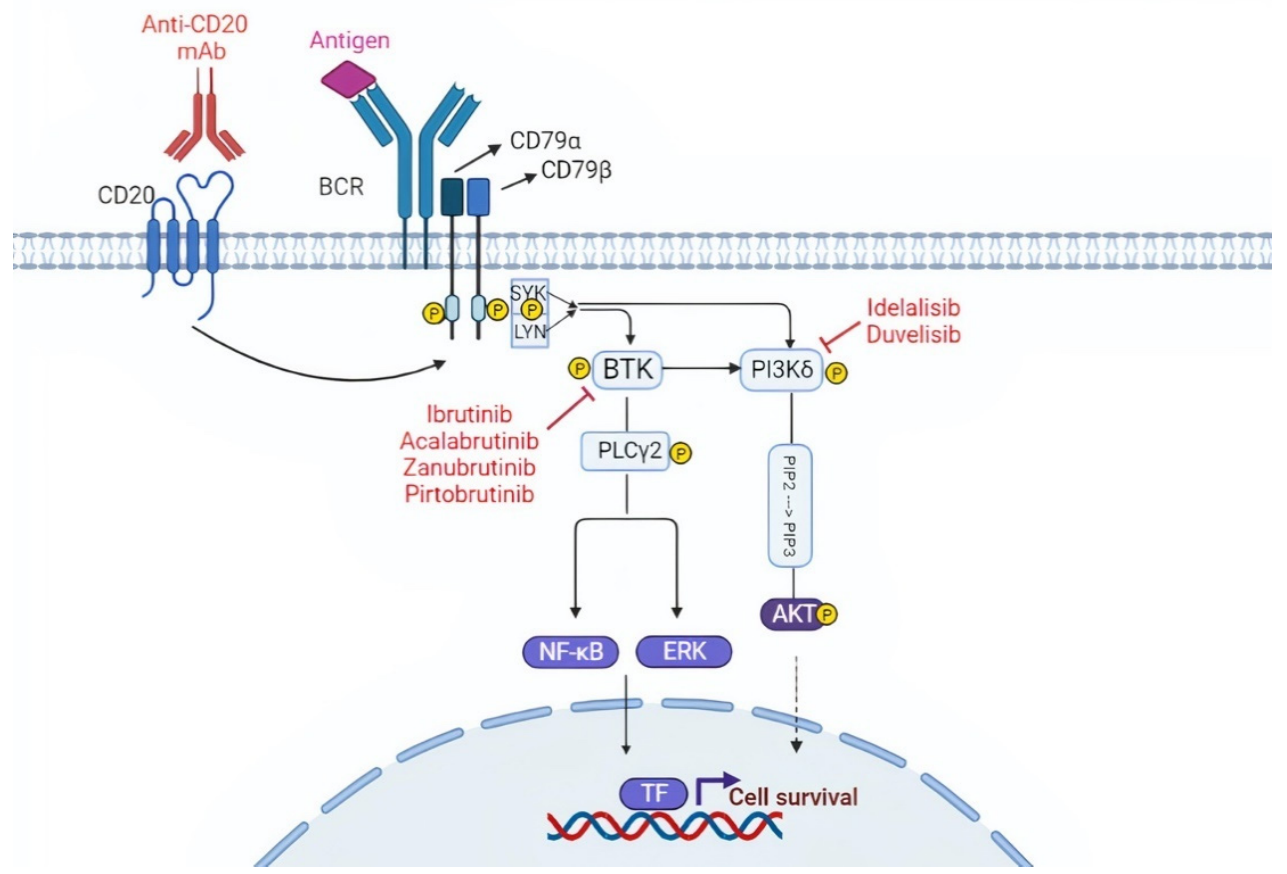

Figure 1. Targeting the $\mathrm{B}$ cell receptor $(\mathrm{BCR})$ signaling pathway. The $\mathrm{BCR}$ is constituted of a membrane immunoglobulin attached to the CD79a/CD79b complex. The antigen binding leads to the interaction between the ITAM domain of CD79a/CD79b and the Syk and Lyn kinases. This interaction triggers the downstream BCR signaling cascade. BTK and PI3K play a pivotal role in the BCR cascade and drugs that inhibit these two molecules are represented in the figure. $\mathrm{TF}$, transcription factors.

The BCR is connected to a network of kinases and phosphatases that regulate and amplify its activation. Upon antigen binding, the BCR initiates a signaling cascade through the phosphorylation of $\operatorname{Ig} \alpha(C D 79 \alpha)$ and $\operatorname{Ig} \beta(C D 79 \beta)$ by Lyn and other Src family kinases. These events are followed by the activation of other kinases, namely SYK, Bruton tyrosine kinase (BTK), and phosphoinositide-3 kinases (PI3Ks), which will transmit the signal to downstream pathways important for B-cell growth and survival, including AKT, ERK, and NF-kB (Figure 1) [19].

As stated above, BCR signaling is essential for CLL pathogenesis and proliferation and can be targeted in vivo by inhibiting the BTK that plays a pivotal role in the BCR cascade. Different BTK inhibitors (BTKi) with different modes of action are currently used or are in development in advanced stage clinical trials. In addition to BTK, PI3K is also a druggable target in CLL.

\subsection{BTK Inhibitors}

BTK is a crucial intracellular protein downstream of the BCR, whose expression is upregulated in CLL cells [25]. BTKi are small, orally available molecules that bind to the Cys481 residue near to the ATP-binding domain of the BTK protein by covalent or non-covalent bonds. This active occupancy of the ATP binding domain inhibits the subsequent phosphorylation of BTK and blocks the downstream signaling pathways, including AKT and NF-kB, which regulate cell survival and proliferation. BTKi can be 
grouped into covalent BTKi (ibrutinib, acalabrutinib, and zanubrutinib) and non-covalent BTKi (pirtobrutinib) [26,27].

CLL patients may develop resistance against BTKi by different mechanisms, including mutations of the BTK binding site and of the gene encoding phospholipase C Gamma 2 (PLCG2), which acts downstream of BTK in the BCR signaling cascade. BTK mutations are represented by substitutions of the Cys481 residue with a different amino acid, leading to the loss of the bond between the drug and the kinase. PLCG2 alterations are gain of function mutations, which can activate downstream BCR signaling independent of BTK inhibition. Both BTK mutations and PLCG2 mutations lead to loss of the activity of the BTKi $[25,28,29]$.

\subsubsection{Ibrutinib}

Ibrutinib, the first-in-class covalent BTKi, has significantly changed the natural history and the management of CLL patients [25]. Ibrutinib can induce off-target effects by inhibiting other kinases that have a corresponding cysteine residue in the ATP binding site similar to BTK, such as epidermal-derived growth factor receptor (EGFR) family kinases, TEC family proteins, and interleukin-2-inducible tyrosine kinase (ITK). These off- target inhibition cause undesired side effects, which might limit the treatment, such as atrial fibrillation (AF) and bleeding [30,31].

Long-term outcomes of pivotal early phase studies have demonstrated durable responses with progression-free survival (PFS) rates that at 7 years exceed $80 \%$ in treatmentnaïve patients [32]. Importantly, these reports highlight that ibrutinib is highly active also in TP53-disrupted patients, in which the drug allows to achieve a 6-year PFS and overall survival (OS) of $61 \%$ and $79 \%$, respectively [33]. Subsequent phase 3 trials of ibrutinib single agent or in combination with anti-CD20 monoclonal antibodies $(\mathrm{mAb})$ have shown that the drug significantly prolongs outcomes of both young and fit CLL patients and elderly patients with comorbidities compared to CIT regimens [34-36]. Interestingly, ibrutinib completely overcomes the negative prognostic impact of unmutated IGHV genes, and since its mode of action is independent of TP53, it also smoothens the detrimental impact of TP53 disruption in CLL cells [37] (Table 2).

Table 2. Clinical trials in CLL.

\begin{tabular}{|c|c|c|c|c|c|c|}
\hline Trial & Phase & Setting & Interventions & N. of Patients & PFS & OS \\
\hline \multirow{2}{*}{$\begin{array}{c}\text { Ibrutinib-Rituximab or } \\
\text { Chemoimmunotherapy } \\
\text { for Chronic Lymphocytic } \\
\text { Leukemia [34] }\end{array}$} & \multirow[b]{2}{*}{3} & \multirow{2}{*}{$\begin{array}{l}\text { Untreated patients with } \\
\text { CLL or SLL subtype of } \\
\text { CLL }\end{array}$} & Ibrutinib-Rituximab & 354 & 3 years: $89.4 \%$ & 3 years: $98.8 \%$ \\
\hline & & & $\begin{array}{l}\text { Chemoimmunotherapy } \\
\text { (FCR) }\end{array}$ & 175 & 3 years: $72.9 \%$ & 3 years: $91.5 \%$ \\
\hline \multirow{2}{*}{$\begin{array}{c}\text { Venetoclax and } \\
\text { Obinutuzumab in Patients } \\
\text { with CLL and Coexisting } \\
\text { Conditions [38] }\end{array}$} & \multirow[b]{2}{*}{3} & \multirow{2}{*}{$\begin{array}{l}\text { Untreated patients with } \\
\text { CLL }\end{array}$} & $\begin{array}{c}\text { Venetoclax }+ \\
\text { Obinutuzumab }\end{array}$ & 216 & $\begin{array}{l}24 \text { months: } \\
88.2 \%\end{array}$ & $\begin{array}{l}24 \text { months: } \\
91.8 \%\end{array}$ \\
\hline & & & $\begin{array}{l}\text { Chlorambucil + } \\
\text { Obinutuzumab }\end{array}$ & 216 & $\begin{array}{l}24 \text { months: } \\
64.1 \%\end{array}$ & $\begin{array}{l}24 \text { months: } \\
93.3 \%\end{array}$ \\
\hline \multirow{3}{*}{$\begin{array}{l}\text { Ibrutinib Regimens versus } \\
\text { Chemoimmunotherapy in } \\
\text { Older Patients with } \\
\text { Untreated CLL [36] }\end{array}$} & \multirow{3}{*}{3} & \multirow{3}{*}{$\begin{array}{l}\text { Untreated patients with } \\
\quad \text { CLL aged } \geq 65\end{array}$} & $\begin{array}{l}\text { Bendamustine }+ \\
\text { Rituximab }\end{array}$ & 183 & 24 months: $74 \%$ & 24 months: $95 \%$ \\
\hline & & & Ibrutinib & 182 & 24 months: $87 \%$ & 24 months: $90 \%$ \\
\hline & & & Ibrutinib + Rituximab & 182 & 24 months: $88 \%$ & 24 months: $94 \%$ \\
\hline \multirow{2}{*}{$\begin{array}{c}\text { Ibrutinib plus } \\
\text { obinutuzumab versus } \\
\text { chlorambucil plus } \\
\text { obinutuzumab in first-line } \\
\text { treatment of chronic } \\
\text { lymphocytic leukaemia } \\
\text { (iLLUMINATE): a } \\
\text { multicentre, randomised, } \\
\text { open-label, phase 3 } \\
\text { trial [39] }\end{array}$} & \multirow[b]{2}{*}{3} & \multirow{2}{*}{$\begin{array}{l}\text { Untreated patients with } \\
\text { CLL or SLL either aged } \\
65 \text { years or older or } \\
\text { younger than } 65 \text { years } \\
\text { with coexisting } \\
\text { conditions }\end{array}$} & $\begin{array}{c}\text { Ibrutinib }+ \\
\text { Obinutuzumab }\end{array}$ & 113 & $\begin{array}{l}\text { Median PFS: not } \\
\text { reached } \\
\text { (Estimated) } \\
30 \text { months: } 79 \% \\
\end{array}$ & $\begin{array}{c}\text { Median OS: not } \\
\text { reached } \\
\text { (Estimated) } \\
30 \text { months: } 86 \% \\
\end{array}$ \\
\hline & & & $\begin{array}{l}\text { Chlorambucil + } \\
\text { Obinutuzumab }\end{array}$ & 116 & $\begin{array}{l}\text { Median PFS: } 19 \\
\text { months } \\
\text { (Estimated) } \\
30 \text { months: } 31 \%\end{array}$ & $\begin{array}{l}\text { Median OS: not } \\
\text { reached at } \\
\text { (Estimated) } \\
30 \text { months: } 85 \%\end{array}$ \\
\hline
\end{tabular}


Table 2. Cont.

\begin{tabular}{|c|c|c|c|c|c|c|}
\hline Trial & Phase & Setting & Interventions & N. of Patients & PFS & OS \\
\hline \multirow{2}{*}{$\begin{array}{c}\text { Long-term follow-up of } \\
\text { the } \\
\text { RESONATE phase } 3 \text { trial } \\
\text { of Ibrutinib vs. } \\
\text { Ofatumumab [37] }\end{array}$} & \multirow[b]{2}{*}{3} & \multirow{2}{*}{$\begin{array}{l}\text { Previously treated } \\
\text { patients with CLL or } \\
\text { SLL requiring a new } \\
\text { therapy and not } \\
\text { eligible for purine } \\
\text { analog-based therapy }\end{array}$} & Ibrutinib & 195 & $\begin{array}{l}\text { Median PFS: not } \\
\text { reached } \\
3 \text { years: } 59 \%\end{array}$ & $\begin{array}{l}\text { Median OS: not } \\
\text { reached } \\
3 \text { years: } 74 \%\end{array}$ \\
\hline & & & $\begin{array}{c}\text { Ofatumumab } \\
\text { [Note: } 68 \% \text { of patients } \\
\text { in this arm crossing } \\
\text { over to ibrutinib] }\end{array}$ & 196 & $\begin{array}{c}\text { Median PFS: } 8.1 \\
\text { months } \\
\text { 3 years: } 3 \%\end{array}$ & $\begin{array}{l}\text { Median OS: not } \\
\text { reached } \\
3 \text { years: } 65 \%\end{array}$ \\
\hline \multirow{2}{*}{$\begin{array}{c}\text { Venetoclax-Rituximab in } \\
\text { Relapsed or Refractory } \\
\text { Chronic Lymphocytic } \\
\text { Leukemia [40] }\end{array}$} & \multirow{2}{*}{3} & \multirow{2}{*}{$\begin{array}{l}\text { Patients aged } 18 \text { years } \\
\text { or older with relapsed } \\
\text { or refractory CLL }\end{array}$} & $\begin{array}{l}\text { Venetoclax }+ \\
\text { Rituximab }\end{array}$ & 194 & $\begin{array}{c}2 \text { years overall: } \\
84.9 \%\end{array}$ & $\begin{array}{c}2 \text { years overall: } \\
91.9 \%\end{array}$ \\
\hline & & & $\begin{array}{l}\text { Bendamustine }+ \\
\text { Rituximab }\end{array}$ & 195 & $\begin{array}{c}2 \text { years overall: } \\
36.3 \%\end{array}$ & $\begin{array}{c}2 \text { years overall: } \\
86.6 \%\end{array}$ \\
\hline \multirow{2}{*}{$\begin{array}{c}\text { Acalabrutinib Versus } \\
\text { Ibrutinib in } \\
\text { Previously Treated } \\
\text { Chronic Lymphocytic } \\
\text { Leukemia: Results of the } \\
\text { First Randomized Phase } \\
\text { III Trial [41] }\end{array}$} & \multirow{2}{*}{3} & \multirow{2}{*}{$\begin{array}{l}\text { Patients with } \\
\text { previously treated CLL } \\
\text { with centrally } \\
\text { confirmed } \\
\text { del }(17)(\mathrm{p} 13.1) \text { or } \\
\text { del }(11)(\mathrm{q} 22.3)\end{array}$} & Ibrutinib & 265 & $\begin{array}{l}\text { Median PFS: } \\
34.8 \text { months }\end{array}$ & $\begin{array}{l}\text { Median OS: not } \\
\text { reached } \\
3 \text { years: }>60 \%\end{array}$ \\
\hline & & & Acalabrutinib & 268 & $\begin{array}{l}\text { Median PFS: } \\
34.8 \text { months }\end{array}$ & $\begin{array}{l}\text { Median OS: not } \\
\text { reached } \\
\text { 3 years: }>60 \%\end{array}$ \\
\hline \multirow{3}{*}{$\begin{array}{c}\text { Acalabrutinib with or } \\
\text { without obinutuzumab } \\
\text { versus chlorambucil and } \\
\text { Obinutuzumab for } \\
\text { treatment-naive chronic } \\
\text { lymphocytic leukaemia } \\
\text { (ELEVATE TN): a } \\
\text { randomised, controlled, } \\
\text { phase } 3 \text { trial [42] }\end{array}$} & \multirow{3}{*}{3} & \multirow{3}{*}{$\begin{array}{l}\text { Untreated patients with } \\
\text { CLL ged } 65 \text { years or } \\
\text { older, or older than } \\
18 \text { years and younger } \\
\text { than } 65 \text { years with } \\
\text { creatinine clearance of } \\
30-69 \mathrm{~mL} / \mathrm{min} \text { or } \\
\text { Cumulative Illness } \\
\text { Rating Scale for } \\
\text { Geriatrics score greater } \\
\text { than } 6 \text {. }\end{array}$} & Acalabrutinib & 179 & $\begin{array}{l}\text { Median PFS not } \\
\text { reached }\end{array}$ & $\begin{array}{l}\text { Median OS: not } \\
\text { reached } \\
3 \text { years: }>80 \%\end{array}$ \\
\hline & & & $\begin{array}{l}\text { Acalabrutinib + } \\
\text { Obinutuzumab }\end{array}$ & 179 & $\begin{array}{l}\text { Median PFS not } \\
\text { reached }\end{array}$ & $\begin{array}{l}\text { Median OS: not } \\
\text { reached } \\
3 \text { years: }>80 \%\end{array}$ \\
\hline & & & $\begin{array}{l}\text { Chlorambucil + } \\
\text { Obinutuzumab }\end{array}$ & 177 & $\begin{array}{l}\text { Median PFS: } \\
22.6 \text { months }\end{array}$ & $\begin{array}{l}\text { Median OS: not } \\
\text { reached } \\
3 \text { years: }>80 \%\end{array}$ \\
\hline \multirow{2}{*}{$\begin{array}{c}\text { The phase } 3 \text { DUO trial: } \\
\text { duvelisib vs. ofatumumab } \\
\text { in relapsed and refractory } \\
\text { CLL/SLL }\end{array}$} & \multirow{2}{*}{3} & \multirow{2}{*}{$\begin{array}{l}\text { Relapsed or refractory } \\
\text { CLL/SLL [43] }\end{array}$} & Duvelisib & 160 & $\begin{array}{l}\text { Median PFS: } \\
13.3 \text { months }\end{array}$ & $\begin{array}{l}\text { Median OS: not } \\
\text { reached } \\
3 \text { years: }>50 \%\end{array}$ \\
\hline & & & Ofatumumab & 159 & $\begin{array}{l}\text { Median PFS: } 9.9 \\
\text { months }\end{array}$ & $\begin{array}{l}\text { Median OS: not } \\
\text { reached } \\
3 \text { years: }>50 \%\end{array}$ \\
\hline
\end{tabular}

\subsubsection{Acalabrutinib}

Acalabrutinib is a more potent and selective inhibitor of BTK in comparison to ibrutinib, and given the lower activity of the drug against other kinases (e.g., ITK, EGFR, ERBB2), it is less likely to cause off-target adverse events [44,45]. Acalabrutinib has demonstrated superior PFS compared to CIT or to the PI3K $\delta$ inhibitor idelalisib in a phase 3 study dedicated to relapsed/refractory ( $R / R$ ) patients (ASCEND trial) [46]. Furthermore, acalabrutinib single agent or in combination with the anti-CD20 mAb Obinutuzumab has been shown to prolong PFS in first-line setting in elderly CLL patients with comorbidities (ELEVATE-TN trial) [42]. Because of its higher affinity for BTK, acalabrutinib has also demonstrated high efficacy and tolerability in ibrutinib-intolerant patients with CLL [47,48].

Recently, a head-to-head comparison of ibrutinib versus acalabrutinib has been carried out in a phase 3 trial dedicated to R/R CLL patients (ELEVATE-RR). This trial has demonstrated the non-inferiority of acalabrutinib compared to ibrutinib in terms of PFS and has documented that acalabrutinib associates with an improved safety profile with fewer AF events and discontinuations because of adverse events [41] (Table 2).

\subsubsection{Zanubrutinib}

Zanubrutinib is a next-generation BTKi with favorable oral bioavailability and high specificity for BTK, exhibiting lower off-target activity than ibrutinib for structurally related kinases, such as EGFR and ITK [49]. Phase 2 studies in both the treatment naïve (TN) and R/R CLL with TP53 disruption have shown an overall response rate (ORR) of more 
than $85 \%$ [50-52]. Recently, an interim analysis of a phase 3 randomized, controlled trial comparing ibrutinib versus zanubrutinib in R/R CLL patients has demonstrated that zanubrutinib has a superior response rate, an improved PFS, and a lower rate of atrial fibrillation/flutter compared to ibrutinib [53].

\subsubsection{Pirtobrutinib}

The most common mechanisms of resistance to covalent BTKi include mutations at the binding site of the drugs (BTK Cys481) and gain-of-function mutations of the downstream PLC $\gamma 2$ phospholipase [54,55]. Pirtobrutinib is an orally available, highly selective, reversible BTKi with equal low $\mathrm{nM}$ potency against both wild-type and Cys481-mutated BTK [56]. In a phase 1/2 study of pirtobrutinib in B-cell malignances, the ORR of R/R CLL patients to pirtobutinib was 62\% [57]. The ORR was similar in CLL patients who had been exposed and become resistant to covalent BTKi, had developed intolerance to covalent BTKi, had acquired a Cys481 mutation in the BTK gene, or had a BTK wild-type disease [57]. In terms of side effects, pirtobrutinib demonstrated a good safety profile. In fact, grade 3 AF or flutter was not observed, and only $1 \%$ of patients discontinued treatment due to a therapy-related adverse event [57].

\subsection{PI3K Inhibitors}

PI3Ks are a family of enzymes involved in cellular functions, such as cell growth, proliferation, differentiation, and survival, and are frequently dysregulated in cancers. PI3K are subdivided into three classes, termed as class I, II, and III. Class I PI3Ks comprise four isoforms, namely PI3K- $\alpha,-\beta,-\gamma$, and $-\delta$. The PI $3 \mathrm{~K} \delta$ isoform is a kinase that amplifies and transduces signals from the BCR on the cell surface to the downstream AKT signaling pathway and is the most relevant target in CLL [12,58]. PI3Ki are small, orally available molecules that bind the ATP binding pocket of the PI3K. As a consequence, a major survival signaling pathway in CLL cells, involving AKT, will be inhibited [58]. In addition to PI3Ks inhibitors, this pathway can also be inhibited by the AKT o mTOR inhibitors that are in development [59].

PI3Ki molecules have various specificities and affinities to bind the different PI3K isoforms. One of the major challenges in the development of PI3Ki is the inability to achieve an optimal molecule that can target a specific isoform. The toxicities from these small-molecules depend on their degree of PI3K isoform specificity [60]. As previously described, different PI3K isoforms are present in human cells, and the isoform $\delta$ is a suitable target in CLL cells [61]. Two PI3Ki have been tested in advanced stage clinical trials, namely idelalisib and duvelisib.

\subsubsection{Idelalisib}

Idelalisib is the first commercially approved PI3K $\delta$ inhibitor for patients with CLL. This molecule demonstrated meaningful clinical activities in R/R patients in the context of phase 2 clinical trials [62]. The phase 3 trial compared idelalisib-rituximab with placeborituximab in R/R CLL [63,64]. Idelalisib-rituximab resulted in superior PFS (not reached vs. 5.5 months) and OS at 12 months (92\% vs. 80\%) [63,64]. Patients with high-risk disease features, such as TP53 aberrations or IGHV unmutated status, had similar PFS to those without such features $[63,64]$. Adverse events included neutropenia $(65 \%)$, transaminitis $(39 \%)$, and diarrhea or colitis in $36 \%$ of patients. Opportunistic $P$ jirovecii infections were seen in patients who had not received prophylaxis $[63,64]$.

\subsubsection{Duvelisib}

The efficacy of idelalisib encouraged development of other PI3Ki. Duvelisib is an oral dual inhibitor of PI3Kd and PI3Kg that is uniquely positioned to target both intracellular and extracellular survival signals [65]. Considering all tested dose levels, adverse events were similar to those reported for idelalisib, with neutropenia (39\%), increased transaminase levels (39\%), and diarrhea (42\%). Early efficacy data in CLL were promising, with a 56\% 
ORR and a median PFS of 15.7 months across all dose levels [66]. The subsequent phase 3 trial tested duvelisib versus ofatumumab (an anti-CD20 monoclonal antibody) in R/R CLL. The median PFS was superior for duvelisib versus ofatumumab (17.6 months versus 9.7 months) [43]. As with idelalisib, PFS was similar in TP53-aberrant and TP53-intact disease [43]. Adverse events were similar to those reported in earlier phase trials, and cases of $P$ jirovecii pneumonia were restricted only to subjects not receiving anti-infectious prophylaxis $[43,67]$ (Table 2$)$.

\section{Targeting the BCL2 Pathway in CLL}

The BCL-2 family contains different members that can be divided into two groups: (i) pro-apoptotic proteins, including multi-domain (e.g., BAK and BAX) or BH3-only proteins (e.g., BIM and PUMA) and (ii) anti-apoptotic proteins, namely BCL2, BCL- $\mathrm{X}_{\mathrm{L}}$, BCL-W, MCL1, BCL-B, and BFL-1 [67,68]. Physiologically, there is a balance between pro-apoptotic and anti-apoptotic actors. BCL2 inhibits apoptosis by sequestering BH3-only proteins that are required for the activation of BAK and BAX (Figure 2) [68,69].

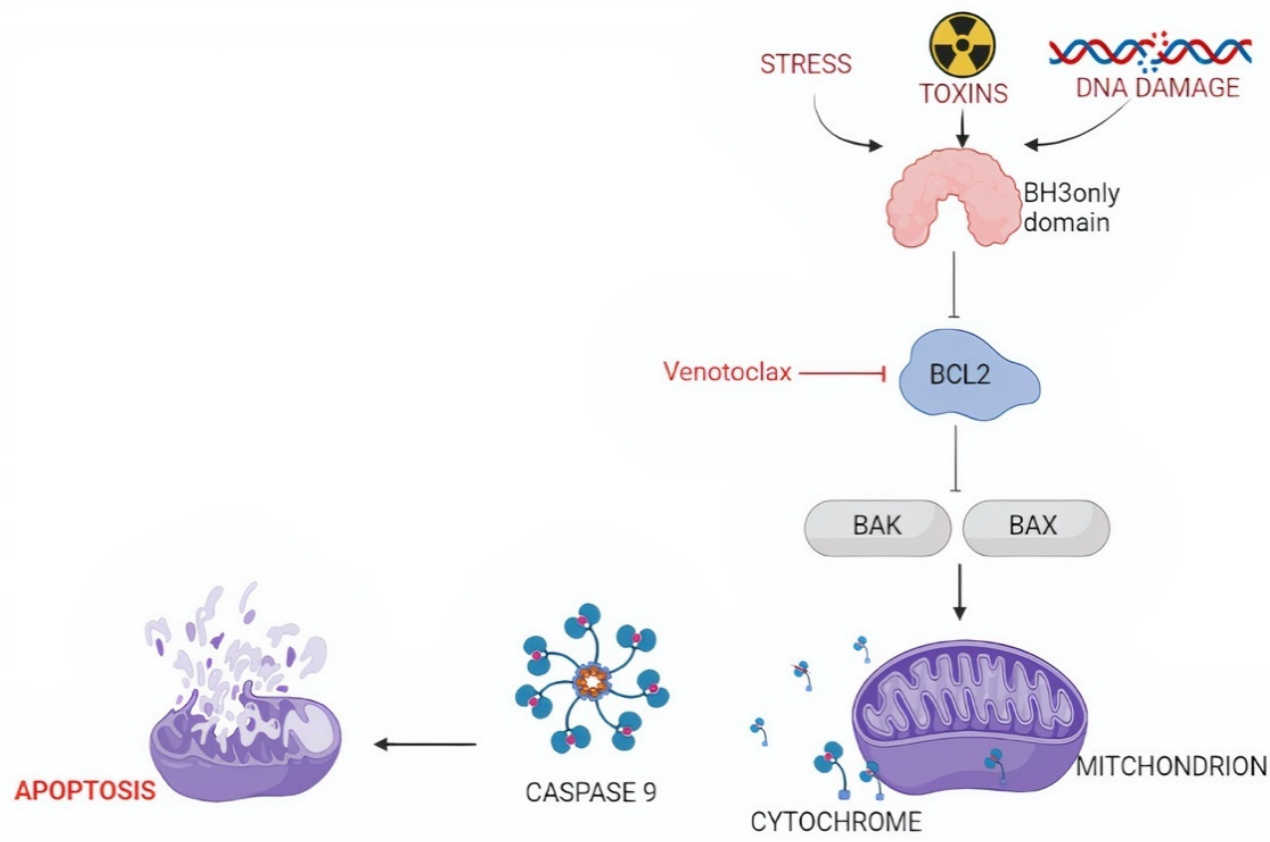

Figure 2. Targeting the intrinsic pathway of apoptosis. The intrinsic pathway of apoptosis is activated by diverse cytotoxic stimuli, including oncogenic stress and chemotherapeutic agents. These pro-apoptotic factors trigger BH3-only proteins, including BIM, to bind and inhibit BCL2. As a consequence of BCL2 inhibition, larger amounts of BAK and BAX will be rendered free. The availability of large amounts of BAK and BAX allows them to dimerize and create a channel for cytochrome c leakage from the mitochondria into the cytoplasm, where it induces cell apoptosis.

CLL cells consistently overexpress BCL2, rendering it an important druggable target. Del13q14, the most common genetic abnormality in CLL, occurs in at least $40-50 \%$ of cases and is a well-documented mechanism of BCL2 deregulation in CLL. Seminal studies identified two microRNAs, termed $m i R-15$ and $m i R-16$, as the relevant genes that are lost because of del13q14 [70]. By binding to specific sequences on BCL2 mRNA, miR-15 and miR16 inhibit the translation of the BCL2 protein. In case of del13q14, the function of $m i R-15$ and $m i R-16$ is lost, and the translation of BCL2 mRNA is no longer inhibited. Consequently, translation of the BCL2 protein will be enhanced, the cellular levels of BCL2 expression will increase, apoptosis will be prevented, and survival of CLL cells will be promoted [71,72]. 


\section{BCL2 Inhibitors}

Given the pivotal role of BCL2 in the pathogenesis of CLL, different molecules have been designed to target BCL2 in this leukemia. The first BCL2 inhibitor (BCL2i) to be tested in humans was navitoclax [72], which, however, did not selectively inhibit BCL2 but also targeted BCL- $\mathrm{X}_{\mathrm{L}}$. Navitoclax demonstrated meaningful clinical activity in CLL, but its usage was limited by the occurrence of thrombocytopenia regardless of the dose because of the inhibition of BCL- $\mathrm{X}_{\mathrm{L}}$, which is a pro-survival protein relevant for circulating platelets [73]. The search for novel BCL2i subsequently led to the design of venetoclax, which is currently used in hematological malignancies.

Venetoclax is a BH3-mimetic molecule that binds to BCL2 similarly to BH3-only proteins, in particular BIM and BID, but with higher affinity. Consequently, venetoclax inhibits the BCL2 ability to bind and quench BIM and BID. Thus, BIM and BID can interact with $B A X$ and $B A K$ and activate the intrinsic apoptotic cascade. Venetoclax is more specific for BCL2 than for BCL- $\mathrm{X}_{\mathrm{L}}$, and few events of thrombocytopenia have been noted. [74].

The first in-human phase 1 trial of venetoclax in CLL enrolled 116 patients. One of the main adverse events was tumor lysis in the first three patients due to the high efficacy of this molecule in inducing apoptosis [75]. This event led to the introduction of a stepwise intra-patient increase in venetoclax dosage (the so-called ramp-up) and the prophylaxis of tumor-lysis syndrome (TLS). Venetoclax showed great efficacy with 79\% ORR and 20\% complete response (CR) [75]. The subsequent phase 2 study enrolled 107 R/R CLL with 17p deletion. The ORR was $79 \%$, and patients with a high proportion of cells with $17 p$ deletion or with TP53 mutations experienced superimposable outcomes [76]. In another phase 2 trial, venetoclax showed high efficacy also in patients who relapsed after ibrutinib with a PFS and OS at 12 months of $75 \%$ and $91 \%$, respectively [77].

Based on the results obtained in monotherapy and given the synergism of venetoclax with different molecules, venetoclax has also been used in combination with other drugs in different clinical trials. Initial phase $1 \mathrm{~b}$ and 2 studies showed high efficacy of venetoclax in combination with both anti-CD20 antibodies and BTKi $[78,79]$. These results prompted the design of the phase 3 MURANO trial comparing bendamustine-rituximab versus fixedduration venetoclax-rituximab (6 doses of rituximab and 2 years of venetoclax) in R/R CLL. Venetoclax-rituximab significantly improved PFS and OS of CLL patients and was therefore approved for R/R CLL patients [40]. Venetoclax was also combined with the secondgeneration anti-CD20 mAb Obinutuzumab in elderly CLL patients with comorbidities. The CLL14 trial compared venetoclax-Obinutuzumab versus chlorambucil-Obinutuzumab [38]. The treatment duration in both groups consisted of 12 cycles lasting 28 days each. The PFS at 24 months was significantly higher in the venetoclax-Obinutuzumab group than in the chlorambucil-Obinutuzumab group: $88.2 \%$ compared with $64.1 \%(p<0.001)$. This benefit was also observed in patients with TP53 deletion, mutation, or both, and in patients with unmutated IGHV genes [38,80,81].

Results from preclinical studies have pointed to a potential synergy between ibrutinib and venetoclax. In fact, among the anti-apoptotic proteins that are overexpressed in CLL, levels of the anti-apoptotic MCL1 and BCL-X $X_{L}$ proteins are decreased after ibrutinib, while venetoclax selectively antagonizes BCL2 $[82,83]$. The phase 3 GLOW study compared ibrunitib-venetoclax with chlorambucil-Obinutuzumab in elderly CLL patients with comorbidities. Ibrutinib-venetoclax significantly improved PFS compared to chlorambucilObinutuzumab with manageable toxicities [84] (Table 2).

\section{Targeting Notch Signaling in CLL}

The Notch signaling pathway is composed of a family of transmembrane receptors, of which four are present in humans, namely NOTCH1, NOTCH2, NOTCH3, and NOTCH4 [85]. In normal cells, Notch signaling is activated by cell-to-cell contact thanks to the interaction between the Notch extracellular domain (NECD) and a ligand belonging to members of the Delta-like (DLL1, DLL3, DLL4) or Jagged family (JAG1, JAG2). This receptor-ligand interaction triggers two sequential proteolytic cleavages in Notch receptors by A Disintegrin 
and Metalloproteinase domain-containing protein (ADAM) 10/17 and $\gamma$-secretase, which generate three domains, namely (i) NECD; (ii) Notch transmembrane domain (NTMD); and (iii) Notch intracellular domain (NICD) $[85,86]$. The NICD then translocates to the nucleus, associates with the DNA-binding factor RBPJ, and positively regulates gene transcription. The NICD is usually short-lived because the C-terminal portion, known as PEST domain, is recognized by an E3 ubiquitin ligase and degraded (Figure 3) [85].

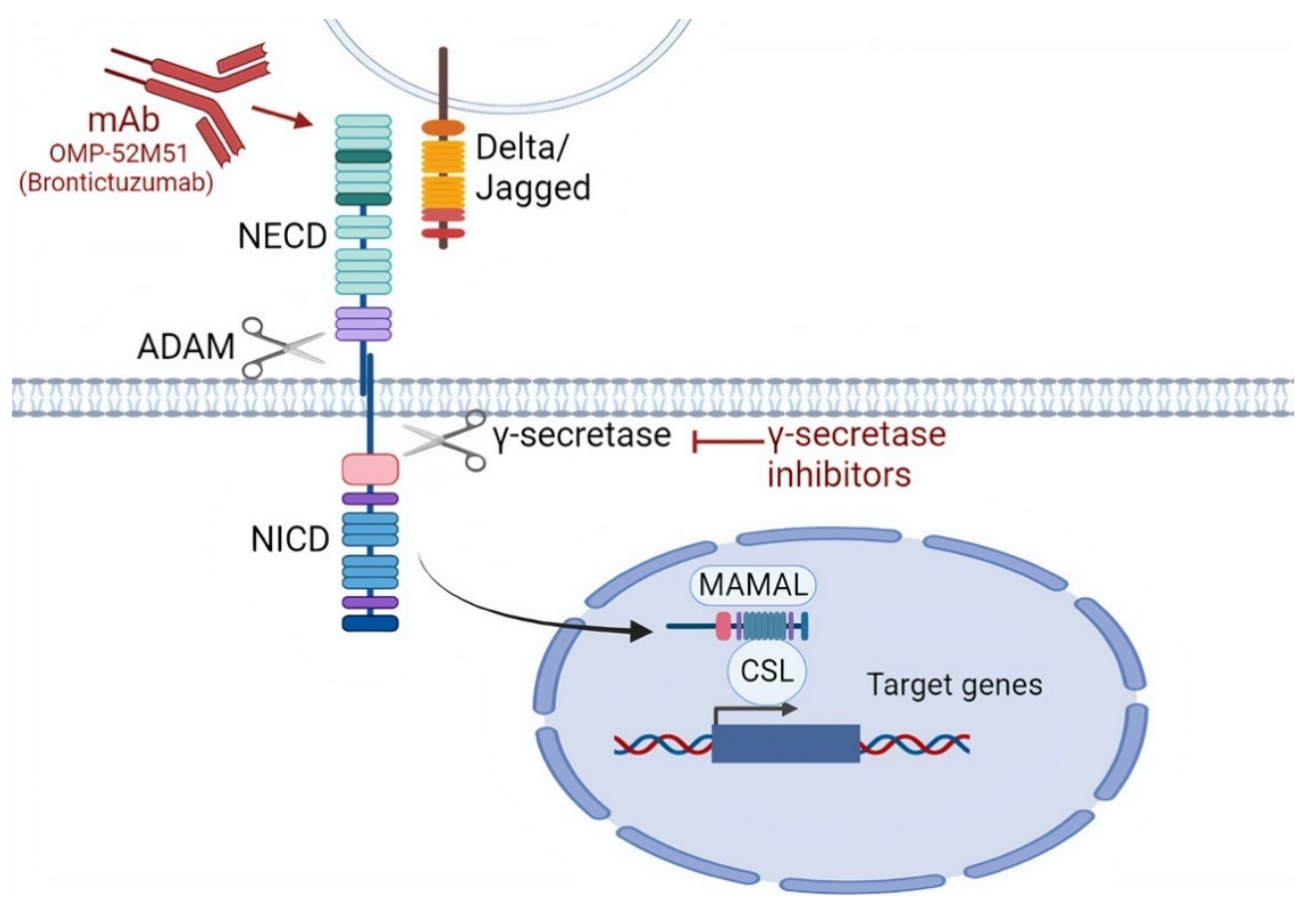

Figure 3. Targeting the NOTCH signaling pathway. NOTCH signaling can be targeted by monoclonal antibodies mAbs that are directed against the NOTCH extra cellular domain (NECD). Other mechanisms of NOTCH inhibition include the targeting by $\gamma$-secretase inhibitors that block $\gamma$-secretase, thus inhibiting the cleavage of NICD, which is necessary for nuclear translocation. As a consequence, $\gamma$-secretase inhibitors prevent the transcriptional activation of NOTCH1 target genes through the suppression of the MAML (Mastermind-like) and CSL (CBF1, Suppressor of Hairless, Lag-1) transcription factors.

In CLL, NOTCH1 is altered in approximately $10-15 \%$ of patients $[11,12]$. Most of NOTCH1 mutations disrupt the PEST domain that is essential for NOTCH1 proteasomal degradation. Consequently, NOTCH1 is no longer ubiquitinated, and consequently, transcription of NOTCH1 target genes is constitutively deregulated. NOTCH1 signaling may also be enhanced by mutations of FBXW7, a gene coding for a NOTCH1 ubiquitinase, whose disruption impairs the ubiquitination of the NOTCH1 protein. Rarely, point mutations in the $3^{\prime} \mathrm{UTR}$ of the NOTCH1 mRNA lead to aberrant splicing events that cause the loss of the NOTCH1 PEST domain $[85,87,88]$.

NOTCH1 mutations associate with shorter survival compared to wild-type patients when treated with CIT. Interestingly, results from the CLL8 trial comparing fludarabine, cyclophosphamide, rituximab (FCR) versus fludarabine, and cyclophosphamide (FC) as first line therapy in CLL patients demonstrated that NOTCH1 mutated patients may not benefit from the addition of the type 1 anti-CD20 mAb rituximab. Conversely, the novel type 2 anti-CD20 mAb Obinutuzumab appears to overcome the refractoriness to anti-CD20 therapy in CLL carrying NOTCH1 mutations [89].

Different studies are exploring potential molecules with different modes of action that may inhibit the NOTCH signaling pathway, including (i) mAbs against a fragment of the human NOTCH1 protein and (ii) $\gamma$ secretase inhibitors. The mAb OMP-52M51 
(Brontictuzumab) has been shown to efficiently block canonical Notch signaling and to decrease Notch activation also in the presence of PEST mutations in vitro [90]. This drug was tested in a phase 1 dose escalation trial (NCT01778439) in patients with previously treated CLL, mantle cell lymphoma, T-lineage acute lymphoblastic leukemia (T-ALL), or other hematologic malignancies but showed limited antitumor efficacy [91]. Concerning $\gamma$-secretase inhibitors, these compounds have been tested in T-ALL showing cell cycle arrest and rapid clearance of intracellular NOTCH1 [85,92]. In CLL, however, the activity of $\gamma$-secretase inhibitors has not been documented.

Although BCRi and BCL2i do not target NOTCH1 directly, these drugs appear to circumvent the negative prognostic impact of NOTCH1 mutations conferred to patients treated with CIT. In this respect, the clinical impact of NOTCH1 mutations in patients treated with BCRi or BCL2i has been addressed by two large prospective studies. Results from the RESONATE and CLL14 clinical trials indicate that arms containing ibrutinib (in the case of RESONATE) or venetoclax (in the case of CLL14) are able to overcome the negative prognostic impact conferred by NOTCH1 mutations $[37,80]$.

\section{Targeting the NF- $\kappa$ B Signaling Pathway in CLL}

Nuclear factor- $\kappa \mathrm{B}(\mathrm{NF}-\kappa \mathrm{B})$ signaling is a key component of the development and evolution of CLL. Two NF- $\kappa$ B pathways exist, namely the canonical and the non-canonical pathways. The canonical pathway is mediated primarily by signals originating from cell surface receptors, such as the BCR, and is activated by the IkB-kinase (IKK) complex [93]. Activation of the IKK complex leads to phosphorylation and subsequent ubiquitin-mediated proteasomal degradation of the inhibitor of NF- $\mathrm{kB}$ proteins (IkBs) [93]. The non-canonical pathway is activated by members of the tumor necrosis factor (TNF) cytokine family. Upon receptor binding, the TRAF3/MAP3K14-TRAF2/BIRC3-negative regulatory complex of non-canonical NF- $\kappa$ B signaling is disrupted. As a consequence, MAP3K14, the central activating kinase of the pathway, is released to induce the phosphorylation and proteasomal processing of $\mathrm{p} 100$, thereby leading to the formation of p52-containing NF- $\mathrm{kB}$ dimers. The p52 protein subsequently dimerizes with RelB and translocates into the nucleus, where it regulates gene transcription (Figure 4) [94].

In CLL, the NF-kB signaling pathway may be deregulated by mutations affecting the BIRC3 gene, which encodes for a component of the TRAF3/MAP3K14-TRAF2/BIRC3negative regulatory complex of non-canonical NF- $\mathrm{KB}$ signaling [9]. Virtually all BIRC3 genetic lesions are frameshift mutations or stop codons clustering in two hotspot regions between amino acids $367-438$ and 537-564. BIRC3 variants are predicted to generate aberrant truncated transcripts that truncate the C-terminal RING domain of BIRC3. The RING domain of BIRC3 harbors the E3 ubiquitin ligase activity that is essential for proteasomal degradation of MAP3K14, the central activating kinase of non-canonical NF- $\mathrm{B}$ signaling. This observation points to non-canonical NF- $\mathrm{BB}$ activation through MAP3K14 stabilization as the predicted functional consequence of BIRC3 mutations in CLL. BIRC3 is mutated in approximately 3-4\% of newly diagnosed CLL and in $25 \%$ of chemo-refractory patients $[17,94,95]$. In addition, recent works evaluated the impact of biallelic BIRC3 loss in CLL cases harboring 11q deletions showing that BIRC3 mutations in del(11q) cells promote clonal advantage in vitro and accelerate leukemic progression [96].

As a prognostic biomarker, BIRC3 mutations significantly associate with shorter PFS in FCR-treated CLL. Additionally, patients with a biallelic disruption of BIRC3 have a shorter time to first treatment when compared to BIRC3 wild-type patients $[17,96]$. Molecular analysis of the MURANO trial dedicated to R/R CLL has further documented the poor prognosis conferred by BIRC3 disruption in CLL patients treated with CIT. In fact, BIRC3mutated patients treated with bendamustine-rituximab experienced a worse outcome compared to wild-type patients. Conversely, in the same trial, the combination of the BCL2 $i$ venetoclax with rituximab was able to overcome the negative impact of BIRC3 mutations [97]. Similarly, the molecular analysis of the CLL14 trial indicated that the combination of a BCL2 $i$ and an anti-CD20 mAb, i.e., Obinutuzumab-venetoclax, but not 
the Obinutuzumab-chlorambucil CIT regimen is an effective therapeutic option for BIRC3mutated patients [80]. BIRC3 is thus emerging as a novel predictive biomarker that might enter the routine clinical practice in the future.
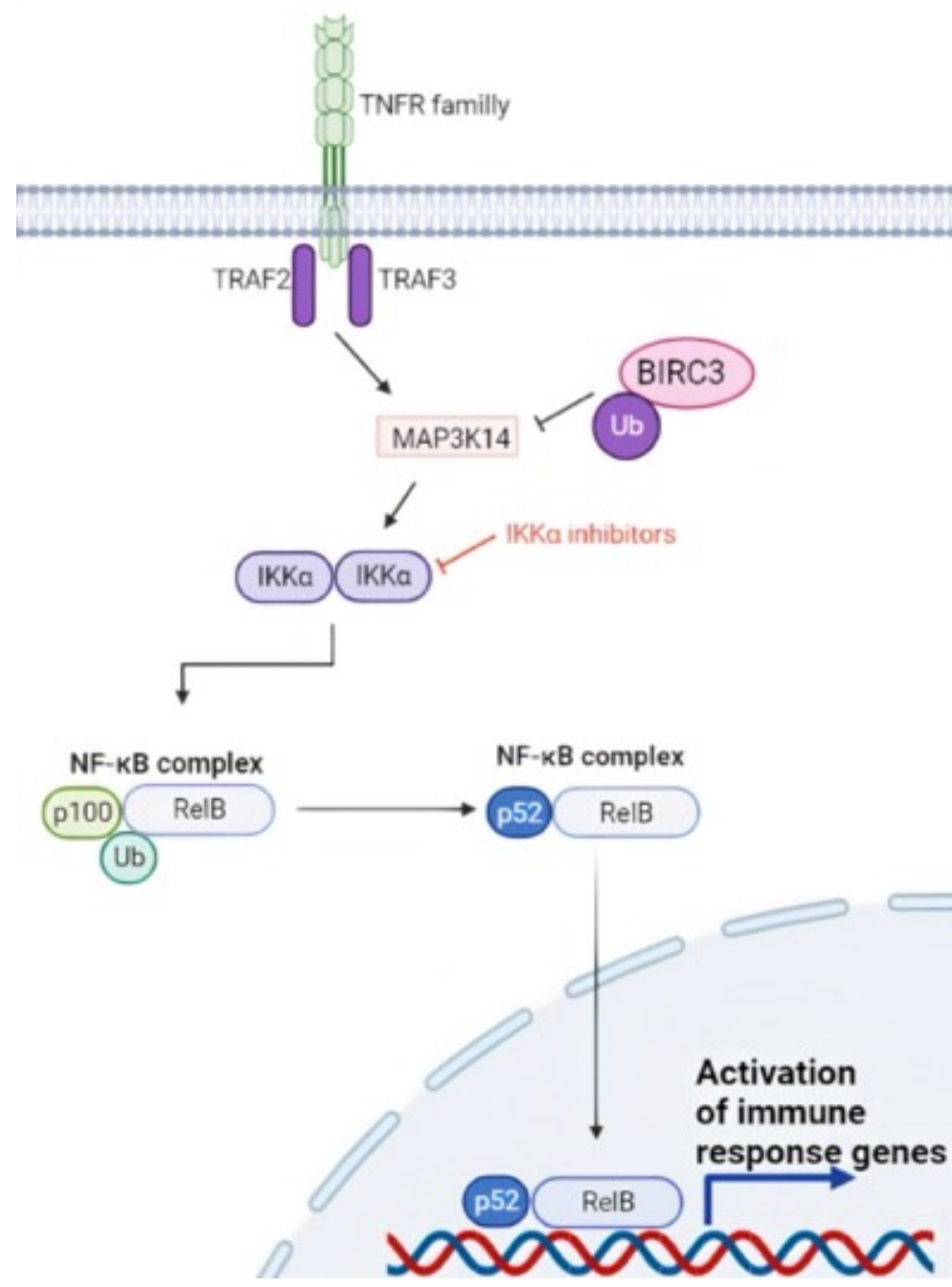

Figure 4. Non canonical NF- $\mathrm{B}$ signaling in CLL. BIRC3 is a negative regulator of the non-canonical NF- $k B$ pathway, and the BIRC3 gene is disrupted by loss of function genetic alterations in a fraction of CLL. BIRC3 physiologically catalyzes the ubiquitination of MAP3K14, leading to inactivation of the NF- $\mathrm{KB}$ pathway. In the case of BIRC3-disrupting mutations, MAP3K14 is no longer ubiquitinated, and therefore, MAP3K14 can perform its function of positive signal transducer activating the NF$\kappa \mathrm{B}$ pathway.

Although direct inhibitors of the NF- $\mathrm{B}$ signaling pathway are not yet available for CLL treatment, the MURANO and the CLL14 trials document that BCL2 inhibition may circumvent and overcome the activation of NF- $\mathrm{KB}$ that is due to BIRC3 disruption in CLL. This observation may be ascribed to the fact that NF- $\kappa B$ signaling induces BCL2 transcription and expression, thus providing a suitable target for the BCL2i venetoclax.

\section{Targeting Molecular Pathways in High-Risk CLL with TP53 Disruption}

In CLL cells with dysfunctional TP53, DNA damage cannot induce cell cycle arrest or DNA repair, enabling the accumulation of substantial levels of DNA alterations that increase genomic instability and thereby lead to the emergence of subclones with additional genetic mutations that can drive CLL progression and transformation [98]. In CLL, the prevalence of TP53 abnormalities, including del17p and TP53 mutations, varies across the different 
phase of the disease. In early stage asymptomatic CLL patients, TP53 abnormalities are detected in approximately $5-7 \%$ of cases [2,99-102]. The frequency of TP53 disruption rises to $40 \%$ in fludarabine-refractory patients and to $60 \%$ in patients with Richter syndrome.

TP53 gene defects represent a key decision-making biomarker in the algorithm for CLL treatment. In fact, del17p13 and TP53 mutations consistently associate with adverse disease outcome in patients treated with CIT due to chemorefractoriness $[2,13,103]$. Assessment of TP53 aberrations is mandatory for patients requiring therapy and must be retested before the initiation of any subsequent line of therapy since clonal evolution can occur $[13,98,104]$. Due to the chemorefractoriness imposed by TP53 disruption, the status of TP53 represents the pivotal decisional node for treatment tailoring in CLL and prompts upfront treatment with BCRi and BCL2i that, at least in part, circumvent TP53-mediated chemorefractoriness. However, both in patients treated with BCRi and with BCL2i, TP53 disruption remains a negative prognostic factor. This concept is important especially in TP53-disrupted patients treated with fixed-duration regimens with BCL2i, indicating the need for more prolonged or continuous treatment in this genetic subset of patients [4].

BCRi and BCL2i do not directly target the TP53 protein but instead exert their antileukemic action through a TP53 independent pathway. Different strategies are currently ongoing with the aim of directly targeting the TP53-dysfunctional protein. APR-246 selectively induces apoptosis in cancer cells with mutant TP53. Mechanistically, APR-246 is able to restore the physiological TP53 conformation and function in cell lines with TP53 missense mutations $[105,106]$. Significant results have been obtained also in vivo in myelodysplastic syndromes and acute myeloid leukemia although results in the CLL are still lacking.

\section{Perspectives}

CLL is the most common type of leukemia in the adult population, and $0.6 \%$ of patients at some point during their lifetime will receive a CLL diagnosis [107]. The recent advances in the understanding of the biology of the disease have allowed the identification of several critical pathways involved in CLL pathogenesis. This has enabled the subsequent design of molecules, namely BTKi and BCL2i, that selectively target at least some of these pathways and changed the therapeutic scenario of CLL patients [4]. In addition, the combination of molecules that inhibit both the BCR and the BCL2 pathway showed and event further activity [84]. In the current therapeutic landscape of CLL, which ranges from CIT to mAb and target therapy, the molecular status of IGHV and TP53 genes provides robust predictors for treatment decision making and must be routinely assessed in the clinical practice in cases requiring treatment [13]. Novel genetic (e.g., BIRC3 and NOTCH1 mutations) and immunogenetic (e.g., stereotyped BCR subset \#2) biomarkers are emerging and have the potential to enter the clinical practice in the future [4]. One important aspect that requires further investigations in the future is the analysis of the genetic complexity and diversity of different anatomical compartments of the disease, mainly represented by the lymph node, bone marrow, and peripheral blood compartments. A recent study in small lymphocytic lymphoma, a disease closely related to CLL, has highlighted that some biological pathways, e.g., NF-kB, may be genetically altered in only one specific anatomical compartment and not in all [108]. This spatial and biological heterogeneity may have important therapeutic implications when targeting specific biological pathways for CLL treatment. Another important topic that will need further investigation is represented by the pivotal role in CLL pathogenies of the interaction between neoplastic B cells and the tissue microenvironment [109].

In the era of precision medicine, CLL is continuing to represent an important disease model in which the molecular and clinical characteristics of the individual patient guide treatment choices. The continuing improvement of the understanding of CLL pathogenesis, coupled with the development of more specific targeted medicines for B-cell malignancies that can spare off-target toxicities, represent an avenue for further improving patients outcomes [110]. 


\begin{abstract}
Author Contributions: Writing-original draft preparation, M.A. (Mohammad Almasri), M.A. (Marah Amer), J.G. and A.M.M.; writing-review and editing, G.G. and R.M. All authors have read and agreed to the published version of the manuscript.

Funding: This work was supported by: Molecular bases of disease dissemination in lymphoid malignancies to optimize curative therapeutic strategies, (5 x 1000 No. 21198), Associazione Italiana per la Ricerca sul Cancro Foundation Milan, Italy; Progetti di Rilevante Interesse Nazionale (PRIN; 2015ZMRFEA), Rome, Italy; the AGING Project-Department of Excellence-DIMET, Università del Piemonte Orientale, Novara, Italy; Ricerca Finalizzata 2018 (project RF-2018-12365790), MoH, Rome, Italy; and Novara-AIL Onlus, Novara, Italy.
\end{abstract}

Institutional Review Board Statement: Not applicable.

Informed Consent Statement: Not applicable.

Data Availability Statement: Not applicable.

Acknowledgments: This work was supported by: Molecular bases of disease dissemination in lymphoid malignancies to optimize curative therapeutic strategies, (5 x 1000 No. 21198), Associazione Italiana per la Ricerca sul Cancro Foundation Milan, Italy; Progetti di Rilevante Interesse Nazionale (PRIN; 2015ZMRFEA), Rome, Italy; the AGING Project-Department of Excellence-DIMET, Università del Piemonte Orientale, Novara, Italy; Ricerca Finalizzata 2018 (project RF-2018-12365790), MoH, Rome, Italy; and Novara-AIL Onlus, Novara, Italy.

Conflicts of Interest: The authors declare no conflict of interest.

\title{
References
}

1. Quintanilla-Martinez, L. The 2016 updated WHO classification of lymphoid neoplasias. Hematol. Oncol. 2017, 35, 37-45. [CrossRef] [PubMed]

2. Gaidano, G.; Rossi, D. The mutational landscape of chronic lymphocytic leukemia and its impact on prognosis and treatment. Hematology 2017, 2017, 329-337. [CrossRef] [PubMed]

3. Landau, D.A.; Tausch, E.; Taylor-Weiner, A.N.; Stewart, C.; Reiter, J.; Bahlo, J.; Kluth, S.; Bozic, I.; Lawrence, M.S.; Böttcher, S.; et al. Mutations driving CLL and their evolution in progression and relapse. Nature 2015, 526, 525-530. [CrossRef] [PubMed]

4. Moia, R.; Patriarca, A.; Schipani, M.; Ferri, V.; Favini, C.; Sagiraju, S.; Al Essa, W.; Gaidano, G. Precision Medicine Management of Chronic Lymphocytic Leukemia. Cancers 2020, 12, 642. [CrossRef]

5. Crombie, J.; Davids, M.S. IGHVmutational status testing in chronic lymphocytic leukemia. Am. J. Hematol. 2017, 92, 1393-1397. [CrossRef] [PubMed]

6. Damle, R.N.; Wasil, T.; Fais, F.; Ghiotto, F.; Valetto, A.; Allen, S.L.; Buchbinder, A.; Budman, D.; Dittmar, K.; Kolitz, J.; et al. Ig V Gene Mutation Status and Cd38 Expression as Novel Prognostic Indicators in Chronic Lymphocytic Leukemia. Blood 1999, 94, 1840-1847. [CrossRef]

7. Hamblin, T.J.; Davis, Z.; Gardiner, A.; Oscier, D.G.; Stevenson, F. Unmutated Ig V(H) genes are associated with a more aggressive form of chronic lymphocytic leukemia. Blood 1999, 94, 1848-1854. [CrossRef]

8. Hacken, E.T.; Burger, J.A. Microenvironment interactions and B-cell receptor signaling in Chronic Lymphocytic Leukemia: Implications for disease pathogenesis and treatment. Biochim. Biophys. Acta 2015, 1863, 401-413. [CrossRef]

9. Fabbri, G.; Dalla-Favera, G.F.R. The molecular pathogenesis of chronic lymphocytic leukaemia. Nat. Cancer 2016, 16, 145-162. [CrossRef]

10. Puente, X.S.; Beà, S.; Valdés-Mas, R.; Villamor, N.; Gutiérrez-Abril, J.; Martín-Subero, J.I.; Munar, M.; Rubio-Pérez, C.; Jares, P.; Aymerich, M.; et al. Non-coding recurrent mutations in chronic lymphocytic leukaemia. Nature 2015, 526, 519-524. [CrossRef]

11. Delgado, J.; Nadeu, F.; Colomer, D.; Campo, E. Chronic lymphocytic leukemia: From molecular pathogenesis to novel therapeutic strategies. Haematologica 2020, 105, 2205-2217. [CrossRef] [PubMed]

12. Putowski, M.; Giannopoulos, K. Perspectives on Precision Medicine in Chronic Lymphocytic Leukemia: Targeting Recurrent Mutations-NOTCH1, SF3B1, MYD88, BIRC3. J. Clin. Med. 2021, 10, 3735. [CrossRef] [PubMed]

13. Hallek, M.; Cheson, B.D.; Catovsky, D.; Caligaris-Cappio, F.; Dighiero, G.; Döhner, H.; Hillmen, P.; Keating, M.; Montserrat, E.; Chiorazzi, N.; et al. iwCLL guidelines for diagnosis, indications for treatment, response assessment, and supportive management of CLL. Blood 2018, 131, 2745-2760. [CrossRef] [PubMed]

14. Minden, M. Is It Time to Redefine Prognostic and Predictive in Oncology? J. Clin. Oncol. 2016, 34, 1702-1703. [CrossRef] [PubMed]

15. Rossi, D.; Rasi, S.; Fabbri, G.; Spina, V.; Fangazio, M.; Forconi, F.; Marasca, R.; Laurenti, L.; Bruscaggin, A.; Cerri, M.; et al. Mutations of NOTCH1 are an independent predictor of survival in chronic lymphocytic leukemia. Blood 2012, 119, 521-529. [CrossRef] [PubMed]

16. Quesada, V.; Conde, L.; Villamor, N.; Ordóñez, G.R.; Jares, P.; Bassaganyas, L.; Ramsay, A.J.; Beà, S.; Pinyol, M.; Martínez-Trillos, A.; et al. Exome sequencing identifies recurrent mutations of the splicing factor SF3B1 gene in chronic lymphocytic leukemia. Nat. Genet. 2011, 44, 47-52. [CrossRef] [PubMed] 
17. Diop, F.; Moia, R.; Favini, C.; Spaccarotella, E.; De Paoli, L.; Bruscaggin, A.; Spina, V.; Terzi-Di-Bergamo, L.; Arruga, F.; Tarantelli, C.; et al. Biological and clinical implications of BIRC3 mutations in chronic lymphocytic leukemia. Haematologica 2019, 105, 448-456. [CrossRef]

18. Kwak, K.; Akkaya, M.; Pierce, S.K. B cell signaling in context. Nat. Immunol. 2019, 20, 963-969. [CrossRef]

19. Tanaka, S.; Baba, Y. B Cell Receptor Signaling. B Cells Immun. Toler. 2020, 1254, 23-36. [CrossRef]

20. Burger, J.A.; Chiorazzi, N. B cell receptor signaling in chronic lymphocytic leukemia. Trends Immunol. 2013, 34, 592-601. [CrossRef]

21. Stevenson, F.K.; Krysov, S.; Davies, A.; Steele, A.J.; Packham, G. B-cell receptor signaling in chronic lymphocytic leukemia. Blood 2011, 118, 4313-4320. [CrossRef] [PubMed]

22. Seda, V.; Mraz, M. B-cell receptor signalling and its crosstalk with other pathways in normal and malignant cells. Eur. J. Haematol. 2014, 94, 193-205. [CrossRef] [PubMed]

23. Stamatopoulos, K.; Agathangelidis, A.; Rosenquist, R.; Ghia, P. Antigen receptor stereotypy in chronic lymphocytic leukemia. Leukemia 2016, 31, 282-291. [CrossRef] [PubMed]

24. Bühler, A.; Zenz, T.; Stilgenbauer, S. Immunoglobulin Heavy Chain Variable Gene Usage and (Super)-antigen Drive in Chronic Lymphocytic Leukemia: Figure 1. Clin. Cancer Res. 2010, 16, 373-375. [CrossRef] [PubMed]

25. Bond, D.A.; Woyach, J.A. Targeting BTK in CLL: Beyond Ibrutinib. Curr. Hematol. Malign. Rep. 2019, 14, 197-205. [CrossRef]

26. Feng, Y.; Duan, W.; Cu, X.; Xin, M. Bruton's tyrosine kinase (BTK) inhibitors in treating cancer: A patent review. Expert Opin. Ther. Pat. 2019, 29, 217-241. [CrossRef]

27. Gaballa, S.; Pinilla-Ibarz, J. BTK Inhibitors in Chronic Lymphocytic Leukemia. Curr. Hematol. Malign. Rep. 2021, 16, 422-432. [CrossRef]

28. Ahn, I.E.; Brown, J.R. Targeting Bruton's Tyrosine Kinase in CLL. Front. Immunol. 2021, 12. [CrossRef]

29. George, B.; Chowdhury, S.M.; Hart, A.; Sircar, A.; Singh, S.K.; Nath, U.K.; Mamgain, M.; Singhal, N.K.; Sehgal, L.; Jain, N. Ibrutinib Resistance Mechanisms and Treatment Strategies for B-Cell Lymphomas. Cancers 2020, 12, 1328. [CrossRef]

30. Kaur, V.; Swami, A. Ibrutinib in CLL: A focus on adverse events, resistance, and novel approaches beyond ibrutinib. Ann. Hematol. 2017, 96, 1175-1184. [CrossRef]

31. Ganatra, S.; Sharma, A.; Shah, S.; Chaudhry, G.M.; Martin, D.T.; Neilan, T.G.; Mahmood, S.S.; Barac, A.; Groarke, J.D.; Hayek, S.; et al. Ibrutinib-Associated Atrial Fibrillation. JACC Clin. Electrophysiol. 2018, 4, 1491-1500. [CrossRef] [PubMed]

32. Byrd, J.C.; Furman, R.R.; Coutre, S.E.; Flinn, I.W.; Burger, J.A.; Blum, K.; Sharman, J.P.; Wierda, W.; Zhao, W.; Heerema, N.A.; et al. Ibrutinib Treatment for First-Line and Relapsed/Refractory Chronic Lymphocytic Leukemia: Final Analysis of the Pivotal Phase Ib/II PCYC-1102 Study. Clin. Cancer Res. 2020, 26, 3918-3927. [CrossRef] [PubMed]

33. Ahn, I.E.; Tian, X.; Wiestner, A. Ibrutinib for Chronic Lymphocytic Leukemia with TP53 Alterations. N. Engl. J. Med. 2020, 383, 498-500. [CrossRef] [PubMed]

34. Shanafelt, T.D.; Wang, X.V.; Kay, N.E.; Hanson, C.A.; O’Brien, S.; Barrientos, J.; Jelinek, D.F.; Braggio, E.; Leis, J.F.; Zhang, C.C.; et al. Ibrutinib-Rituximab or Chemoimmunotherapy for Chronic Lymphocytic Leukemia. N. Engl. J. Med. 2019, 381, 432-443. [CrossRef]

35. Burger, J.A.; Barr, P.M.; Robak, T.; Owen, C.; Ghia, P.; Tedeschi, A.; Bairey, O.; Hillmen, P.; Coutre, S.E.; Devereux, S.; et al. Long-term efficacy and safety of first-line ibrutinib treatment for patients with CLL/SLL: 5 years of follow-up from the phase 3 RESONATE-2 study. Leukemia 2019, 34, 787-798. [CrossRef]

36. Woyach, J.A.; Ruppert, A.S.; Heerema, N.A.; Zhao, W.; Booth, A.M.; Ding, W.; Bartlett, N.; Brander, D.M.; Barr, P.M.; Rogers, K.A.; et al. Ibrutinib Regimens versus Chemoimmunotherapy in Older Patients with Untreated CLL. N. Engl. J. Med. 2018, 379, 2517-2528. [CrossRef]

37. Byrd, J.C.; Hillmen, P.; O’Brien, S.; Barrientos, J.C.; Reddy, N.M.; Coutre, S.; Tam, C.S.; Mulligan, S.P.; Jaeger, U.; Barr, P.M.; et al. Long-term follow-up of the RESONATE phase 3 trial of ibrutinib vs. ofatumumab. Blood 2019, 133, 2031-2042. [CrossRef]

38. Fischer, K.; Al-Sawaf, O.; Bahlo, J.; Fink, A.-M.; Tandon, M.; Dixon, M.; Robrecht, S.; Warburton, S.; Humphrey, K.; Samoylova, O.; et al. Venetoclax and Obinutuzumab in Patients with CLL and Coexisting Conditions. N. Engl. J. Med. 2019, 380, 2225-2236. [CrossRef]

39. Moreno, C.; Greil, R.; Demirkan, F.; Tedeschi, A.; Anz, B.; Larratt, L.; Šimkovič, M.; Samoilova, O.; Novak, J.; Ben-Yehuda, D.; et al. Ibrutinib plus obinutuzumab versus chlorambucil plus obinutuzumab in first-line treatment of chronic lymphocytic leukaemia (iLLUMINATE): A multicentre, randomised, open-label, phase 3 trial. Lancet Oncol. 2018, 20, 43-56. [CrossRef]

40. Seymour, J.F.; Kipps, T.J.; Eichhorst, B.; Hillmen, P.; D’Rozario, J.; Assouline, S.; Owen, C.; Gerecitano, J.; Robak, T.; DE LA Serna, J.; et al. Venetoclax-Rituximab in Relapsed or Refractory Chronic Lymphocytic Leukemia. N. Engl. J. Med. 2018, 378, 1107-1120. [CrossRef]

41. Byrd, J.C.; Hillmen, P.; Ghia, P.; Kater, A.P.; Chanan-Khan, A.; Furman, R.R.; O’Brien, S.; Yenerel, M.N.; Illés, A.; Kay, N.; et al. Acalabrutinib Versus Ibrutinib in Previously Treated Chronic Lymphocytic Leukemia: Results of the First Randomized Phase III Trial. J. Clin. Oncol. 2021, 39, 3441-3452. [CrossRef] [PubMed]

42. Sharman, J.P.; Egyed, M.; Jurczak, W.; Skarbnik, A.; Pagel, J.M.; Flinn, I.W.; Kamdar, M.; Munir, T.; Walewska, R.; Corbett, G.; et al. Acalabrutinib with or without obinutuzumab versus chlorambucil and obinutuzumab for treatment-naive chronic lymphocytic leukaemia (ELEVATE-TN): A randomised, controlled, phase 3 trial. Lancet 2020, 395, 1278-1291. [CrossRef] 
43. Flinn, I.W.; Hillmen, P.; Montillo, M.; Nagy, Z.; Illés, A.; Etienne, G.; Delgado, J.; Kuss, B.J.; Tam, C.S.; Gasztonyi, Z.; et al. The phase 3 DUO trial: Duvelisib vs ofatumumab in relapsed and refractory CLL/SLL. Blood 2018, 132, 2446-2455. [CrossRef] [PubMed]

44. Khan, Y.; O'Brien, S. Acalabrutinib and its use in treatment of chronic lymphocytic leukemia. Futur. Oncol. 2019, 15, 579-589. [CrossRef]

45. Isaac, K.; Mato, A.R. Acalabrutinib and Its Therapeutic Potential in the Treatment of Chronic Lymphocytic Leukemia: A Short Review on Emerging Data. Cancer Manag. Res. 2020, 12, 2079-2085. [CrossRef]

46. Ghia, P.; Pluta, A.; Wach, M.; Lysak, D.; Kozak, T.; Šimkovič, M.; Kaplan, P.; Kraychok, I.; Illes, A.; DE LA Serna, J.; et al. ASCEND: Phase III, Randomized Trial of Acalabrutinib Versus Idelalisib Plus Rituximab or Bendamustine Plus Rituximab in Relapsed or Refractory Chronic Lymphocytic Leukemia. J. Clin. Oncol. 2020, 38, 2849-2861. [CrossRef]

47. Awan, F.T.; Schuh, A.; Brown, J.R.; Furman, R.R.; Pagel, J.M.; Hillmen, P.; Stephens, D.M.; Woyach, J.; Bibikova, E.; Charuworn, P.; et al. Acalabrutinib monotherapy in patients with chronic lymphocytic leukemia who are intolerant to ibrutinib. Blood Adv. 2019, 3, 1553-1562. [CrossRef]

48. Rogers, K.A.; Thompson, P.A.; Allan, J.N.; Coleman, M.; Sharman, J.P.; Cheson, B.D.; Jones, D.; Izumi, R.; Frigault, M.M.; Quah, C.; et al. Phase II study of acalabrutinib in ibrutinib-intolerant patients with relapsed/refractory chronic lymphocytic leukemia. Haematologica 2021, 106, 2364-2373. [CrossRef]

49. Guo, Y.; Liu, Y.; Hu, N.; Yu, D.; Zhou, C.; Shi, G.; Zhang, B.; Wei, M.; Liu, J.; Luo, L. Discovery of Zanubrutinib (Bgb-3111), a Novel, Potent, and Selective Covalent Inhibitor of Bruton's Tyrosine Kinase. J. Med. Chem. 2019, 62, 7923-7940. [CrossRef]

50. Tam, C.S.; Trotman, J.; Opat, S.; Burger, J.A.; Cull, G.; Gottlieb, D.; Harrup, R.; Johnston, P.B.; Marlton, P.; Munoz, J.; et al. Phase 1 study of the selective BTK inhibitor zanubrutinib in B-cell malignancies and safety and efficacy evaluation in CLL. Blood 2019, 134, 851-859. [CrossRef]

51. Tam, C.S.; Robak, T.; Ghia, P.; Kahl, B.S.; Walker, P.; Janowski, W.; Simpson, D.; Shadman, M.; Ganly, P.S.; Laurenti, L.; et al. Zanubrutinib monotherapy for patients with treatment-naïve chronic lymphocytic leukemia and 17p deletion. Haematologica 2020, 106, 2354-2363. [CrossRef] [PubMed]

52. Ye, X.; Hu, F.; Zhai, Y.; Qin, Y.; Xu, J.; Guo, X.; Zhuang, Y.; He, J. Hematological toxicities in immune checkpoint inhibitors: A pharmacovigilance study from 2014 to 2019. Hematol. Oncol. 2020, 38, 565-575. [CrossRef] [PubMed]

53. Hillmen, P.; Eichhorst, B.; Brown, J. (Eds.) First Interim Analysis of Alpine Study: Results of a Phase 3 Randomized Study of Zanubrutinib Vs Ibrutinib in Patients with Relapsed/Refractory Chronic Lymphocytic Leukemia/Small Lymphocytic Lymphoma. In Proceedings of the 25th European Hematology Association Annual Congress (EHA25), Virtual Meeting, 11 June 2021.

54. Woyach, J.A.; Ruppert, A.S.; Guinn, D.; Lehman, A.; Blachly, J.S.; Lozanski, A.; Heerema, N.A.; Zhao, W.; Coleman, J.; Jones, D.; et al. BTKC481S-Mediated Resistance to Ibrutinib in Chronic Lymphocytic Leukemia. J. Clin. Oncol. 2017, 35, 1437-1443. [CrossRef]

55. Quinquenel, A.; Fornecker, L.-M.; Letestu, R.; Ysebaert, L.; Fleury, C.; Lazarian, G.; Dilhuydy, M.-S.; Nollet, D.; Guieze, R.; Feugier, P.; et al. Prevalence of BTK and PLCG2 mutations in a real-life CLL cohort still on ibrutinib after 3 years: A FILO group study. Blood 2019, 134, 641-644. [CrossRef] [PubMed]

56. Brandhuber, B.; Gomez, E.; Smith, S.; Eary, T.; Spencer, S.; Rothenberg, S.M.; Andrews, S. LOXO-305, A Next Generation Reversible BTK Inhibitor, for Overcoming Acquired Resistance to Irreversible BTK Inhibitors. Clin. Lymphoma Myeloma Leuk. 2018, 18, S216. [CrossRef]

57. Mato, A.R.; Shah, N.N.; Jurczak, W.; Cheah, C.Y.; Pagel, J.M.; Woyach, J.A.; Fakhri, B.; Eyre, T.A.; Lamanna, N.; Patel, M.R Pirtobrutinib in Relapsed or Refractory B-Cell Malignancies (Bruin): A Phase 1/2 Study. Lancet 2021, 397, 892-901. [CrossRef]

58. Von Keudell, G.; Moskowitz, A.J. The Role of PI3K Inhibition in Lymphoid Malignancies. Curr. Hematol. Malign. Rep. 2019, 14, 405-413. [CrossRef]

59. Bertacchini, J.; Heidari, N.; Mediani, L.; Capitani, S.; Shahjahani, M.; Ahmadzadeh, A.; Saki, N. Targeting PI3K/AKT/mTOR network for treatment of leukemia. Experientia 2015, 72, 2337-2347. [CrossRef]

60. Mishra, R.; Patel, H.; Alanazi, S.; Kilroy, M.; Garrett, J. PI3K Inhibitors in Cancer: Clinical Implications and Adverse Effects. Int. J. Mol. Sci. 2021, 22, 3464. [CrossRef]

61. Patel, K.; Pagel, J.M. Exploring a Future for PI3K Inhibitors in Chronic Lymphocytic Leukemia. Curr. Hematol. Malign. Rep. 2019, 14, 292-301. [CrossRef]

62. Lampson, B.L.; Brown, J.R. The Evolving Use of Phosphatidylinositol 3-Kinase Inhibitors for the Treatment of Chronic Lymphocytic Leukemia. Hematol. Clin. N. Am. 2021, 35, 807-826. [CrossRef] [PubMed]

63. Furman, R.R.; Sharman, J.P.; Coutre, S.E.; Cheson, B.D.; Pagel, J.M.; Hillmen, P.; Barrientos, J.; Zelenetz, A.D.; Kipps, T.J.; Flinn, I.; et al. Idelalisib and Rituximab in Relapsed Chronic Lymphocytic Leukemia. N. Engl. J. Med. 2014, 370, 997-1007. [CrossRef] [PubMed]

64. Sharman, J.P.; Coutre, S.E.; Furman, R.R.; Cheson, B.D.; Pagel, J.M.; Hillmen, P.; Barrientos, J.C.; Zelenetz, A.D.; Kipps, T.J.; Flinn, I.W.; et al. Final Results of a Randomized, Phase III Study of Rituximab With or Without Idelalisib Followed by Open-Label Idelalisib in Patients With Relapsed Chronic Lymphocytic Leukemia. J. Clin. Oncol. 2019, 37, 1391-1402. [CrossRef] [PubMed]

65. Flinn, I.W.; O’Brien, S.; Kahl, B.; Patel, M.; Oki, Y.; Foss, F.F.; Porcu, P.; Jones, J.; Burger, J.A.; Jain, N.; et al. Duvelisib, a novel oral dual inhibitor of PI3K- $\delta, \gamma$, is clinically active in advanced hematologic malignancies. Blood 2018, 131, 877-887. [CrossRef] 
66. O'Brien, S.; Patel, M.; Kahl, B.S.; Horwitz, S.M.; Foss, F.M.; Porcu, P.; Jones, J.; Burger, J.; Jain, N.; Allen, K.; et al. Duvelisib, an oral dual PI3K- $\delta, \gamma$ inhibitor, shows clinical and pharmacodynamic activity in chronic lymphocytic leukemia and small lymphocytic lymphoma in a phase 1 study. Am. J. Hematol. 2018, 93, 1318-1326. [CrossRef]

67. Warren, C.F.A.; Wong-Brown, M.W.; Bowden, N.A. BCL-2 family isoforms in apoptosis and cancer. Cell Death Dis. 2019, 10, 1-12. [CrossRef]

68. Huska, J.D.; Lamb, H.; Hardwick, J.M. Overview of BCL-2 Family Proteins and Therapeutic Potentials. Methods Mol. Biol. 2018, 1877, 1-21. [CrossRef]

69. Peña-Blanco, A.; Garcia-Saez, A.J. Bax, Bak and beyond-Mitochondrial performance in apoptosis. FEBS J. 2018, $285,416-431$. [CrossRef]

70. Ruefli-Brasse, A.; Reed, J.C. Therapeutics targeting Bcl-2 in hematological malignancies. Biochem. J. 2017, 474, 3643-3657. [CrossRef]

71. Cimmino, A.; Calin, G.A.; Fabbri, M.; Iorio, M.V.; Ferracin, M.; Shimizu, M.; Wojcik, S.E.; Aqeilan, R.I.; Zupo, S.; Dono, M.; et al. miR-15 and miR-16 induce apoptosis by targeting BCL2. Proc. Natl. Acad. Sci. USA 2005, 102, 13944-13949. [CrossRef]

72. Vogler, M.; Walter, H.; Dyer, M. Targeting anti-apoptotic BCL2 family proteins in haematological malignancies-From pathogenesis to treatment. Br. J. Haematol. 2017, 178, 364-379. [CrossRef] [PubMed]

73. Yalniz, F.F.; Wierda, W.G. Targeting BCL2 in Chronic Lymphocytic Leukemia and Other Hematologic Malignancies. Drugs 2019, 79, 1287-1304. [CrossRef] [PubMed]

74. Eradat, H. Venetoclax for the Treatment of Chronic Lymphocytic Leukemia. Curr. Hematol. Malign. Rep. 2019, 14, 469-476. [CrossRef] [PubMed]

75. Roberts, A.W.; Davids, M.S.; Pagel, J.M.; Kahl, B.S.; Puvvada, S.D.; Gerecitano, J.F.; Kipps, T.J.; Anderson, M.A.; Brown, J.R.; Gressick, L.; et al. Targeting BCL2 with Venetoclax in Relapsed Chronic Lymphocytic Leukemia. N. Engl. J. Med. 2016, 374, 311-322. [CrossRef] [PubMed]

76. O'Brien, S.; Jones, J.A.; Coutre, S.E.; Mato, A.R.; Hillmen, P.; Tam, C.; Österborg, A.; Siddiqi, T.; Thirman, M.J.; Furman, R.R.; et al. Ibrutinib for patients with relapsed or refractory chronic lymphocytic leukaemia with 17p deletion (RESONATE-17): A phase 2, open-label, multicentre study. Lancet Oncol. 2016, 17, 768-778. [CrossRef]

77. Jones, J.A.; Mato, A.R.; Wierda, W.G.; Davids, M.S.; Choi, M.; Cheson, B.D.; Furman, R.R.; Lamanna, N.; Barr, P.M.; Zhou, L.; et al. Venetoclax for chronic lymphocytic leukaemia progressing after ibrutinib: An interim analysis of a multicentre, open-label, phase 2 trial. Lancet Oncol. 2018, 19, 65-75. [CrossRef]

78. Seymour, L.; Bogaerts, J.; Perrone, A.; Ford, R.; Schwartz, L.H.; Mandrekar, S.; Lin, N.U.; Litière, S.; Dancey, J.; Chen, A.; et al. iRECIST: Guidelines for response criteria for use in trials testing immunotherapeutics. Lancet Oncol. 2017, 18, e143-e152. [CrossRef]

79. Jain, N.; Keating, M.; Thompson, P.; Ferrajoli, A.; Burger, J.; Borthakur, G.; Takahashi, K.; Estrov, Z.; Fowler, N.; Kadia, T.; et al. Ibrutinib and Venetoclax for First-Line Treatment of CLL. N. Engl. J. Med. 2019, 380, 2095-2103. [CrossRef]

80. Tausch, E.; Schneider, C.; Robrecht, S.; Zhang, C.; Dolnik, A.; Bloehdorn, J.; Bahlo, J.; Al-Sawaf, O.; Ritgen, M.; Fink, A.-M.; et al. Prognostic and predictive impact of genetic markers in patients with CLL treated with obinutuzumab and venetoclax. Blood 2020, 135, 2402-2412. [CrossRef]

81. Al-Sawaf, O.; Zhang, C.; Tandon, M.; Sinha, A.; Fink, A.-M.; Robrecht, S.; Samoylova, O.; Liberati, A.M.; Pinilla-Ibarz, J.; Opat, S.; et al. Venetoclax plus obinutuzumab versus chlorambucil plus obinutuzumab for previously untreated chronic lymphocytic leukaemia (CLL14): Follow-up results from a multicentre, open-label, randomised, phase 3 trial. Lancet Oncol. 2020, 21, 1188-1200. [CrossRef]

82. Lu, P.; Wang, S.; Franzen, C.A.; Venkataraman, G.; McClure, R.; Li, L.; Wu, W.; Niu, N.; Sukhanova, M.; Pei, J.; et al. Ibrutinib and venetoclax target distinct subpopulations of CLL cells: Implication for residual disease eradication. Blood Cancer J. 2021, 11, 1-14. [CrossRef] [PubMed]

83. Cervantes-Gomez, F.; Lamothe, B.; Woyach, J.A.; Wierda, W.G.; Keating, M.J.; Balakrishnan, K.; Gandhi, V. Pharmacological and Protein Profiling Suggests Venetoclax (ABT-199) as Optimal Partner with Ibrutinib in Chronic Lymphocytic Leukemia. Clin. Cancer Res. 2015, 21, 3705-3715. [CrossRef] [PubMed]

84. Kater, A.; Owen, C.; Moreno, C.; Follows, G.; Munir, T.; Levin, M.; Benjamini, O.; Janssens, A.; Osterborg, A.; Robak, T. Fixed-Duration Ibrutinib and Venetoclax (I+ V) Versus Chlorambucil Plus Obinutuzumab (Clb+ O) for First-Line (11) Chronic Lymphocytic Leukemia (Cll): Primary Analysis of the Phase 3 Glow Study. In Proceedings of the 2021 European Hematology Association 2021 Virtual Congress, Virtual Meeting, 9-17 June 2021.

85. Katoh, M.; Katoh, M. Precision medicine for human cancers with Notch signaling dysregulation (Review). Int. J. Mol. Med. 2019, 45, 279-297. [CrossRef] [PubMed]

86. Bray, S. Notch signalling in context. Nat. Rev. Mol. Cell Biol. 2016, 17, 722-735. [CrossRef] [PubMed]

87. Meurette, O.; Mehlen, P. Notch Signaling in the Tumor Microenvironment. Cancer Cell 2018, 34, 536-548. [CrossRef]

88. Fabbri, G.; Rasi, S.; Rossi, D.; Trifonov, V.; Khiabanian, H.; Ma, J.; Grunn, A.; Fangazio, M.; Capello, D.; Monti, S.; et al. Analysis of the chronic lymphocytic leukemia coding genome: Role of NOTCH1 mutational activation. J. Exp. Med. 2011, 208, $1389-1401$. [CrossRef] 
89. Stilgenbauer, S.; Schnaiter, A.; Paschka, P.; Zenz, T.; Rossi, M.; Döhner, K.; Bühler, A.; Böttcher, S.; Ritgen, M.; Kneba, M.; et al. Gene mutations and treatment outcome in chronic lymphocytic leukemia: Results from the CLL8 trial. Blood 2014, 123, 3247-3254. [CrossRef]

90. Höring, E.; Sanmarti, B.C.; Xargay-Torrent, S.; E Aulitzky, W.; Van Der Kuip, H.; Campo, E.; López-Guerra, M.; Colomer, L. Notch1 Signaling in NOTCH1-Mutated Mantle Cell Lymphoma Depends on DLL4 and Is a Potential Target for Specific Antibody Therapy. Blood 2016, 128, 1846. [CrossRef]

91. Casulo, C.; Ruan, J.; Dang, N.H.; Gore, L.; Diefenbach, C.; Beaven, A.W.; Castro, J.E.; Porcu, P.; Faoro, L.; Dupont, J.; et al. Safety and Preliminary Efficacy Results of a Phase I First-in-Human Study of the Novel Notch-1 Targeting Antibody Brontictuzumab (OMP-52M51) Administered Intravenously to Patients with Hematologic Malignancies. Blood 2016, 128, 5108. [CrossRef]

92. Pal, D.; Saha, S. Gamma Secretase Inhibitor: Therapeutic Target via NOTCH Signaling in T Cell Acute Lymphoblastic Leukemia. Curr. Drug Targets 2021, 22, 1789-1798. [CrossRef]

93. Gasparini, C.; Celeghini, C.; Monasta, L.; Zauli, G. NF-кB pathways in hematological malignancies. Cell. Mol. Life Sci. 2014, 71, 2083-2102. [CrossRef] [PubMed]

94. Rossi, D.; Fangazio, M.; Rasi, S.; Vaisitti, T.; Monti, S.; Cresta, S.; Chiaretti, S.; Del Giudice, I.; Fabbri, G.; Bruscaggin, A.; et al. Disruption of BIRC3 associates with fludarabine chemorefractoriness in TP53 wild-type chronic lymphocytic leukemia. Blood 2012, 119, 2854-2862. [CrossRef] [PubMed]

95. Raponi, S.; Del Giudice, I.; Ilari, C.; Cafforio, L.; Messina, M.; Cappelli, L.V.; Bonina, S.; Piciocchi, A.; Marinelli, M.; Peragine, N.; et al. Biallelic BIRC 3 inactivation in chronic lymphocytic leukaemia patients with 11q deletion identifies a subgroup with very aggressive disease. Br. J. Haematol. 2018, 185, 156-159. [CrossRef] [PubMed]

96. Quijada-Álamo, M.; Hernández-Sánchez, M.; Rodríguez-Vicente, A.-E.; Pérez-Carretero, C.; Rodríguez-Sánchez, A.; MartínIzquierdo, M.; Alonso-Pérez, V.; García-Tuñón, I.; Bastida, J.M.; Vidal-Manceñido, M.J.; et al. Biological significance of monoallelic and biallelic BIRC3 loss in del(11q) chronic lymphocytic leukemia progression. Blood Cancer J. 2021, 11, 1-11. [CrossRef]

97. Kater, A.P.; Jiang, Y.; Chyla, B.; Seymour, J.F. Response in patients with BIRC3-mutated relapsed/refractory chronic lymphocytic leukemia treated with fixed-duration venetoclax and rituximab. Haematologica 2020, 105, e382-e383. [CrossRef]

98. Moia, R.; Boggione, P.; Mahmoud, A.M.; Kodipad, A.A.; Adhinaveni, R.; Sagiraju, S.; Patriarca, A.; Gaidano, G. Targeting p53 in chronic lymphocytic leukemia. Expert Opin. Ther. Targets 2020, 24, 1239-1250. [CrossRef]

99. A Catherwood, M.; Gonzalez, D.; Donaldson, D.; Clifford, R.; Mills, K.; Thornton, P. Relevance of TP53 for CLL diagnostics. J. Clin. Pathol. 2019, 72, 343-346. [CrossRef]

100. Rossi, D.; Cerri, M.; Deambrogi, C.; Sozzi, E.; Cresta, S.; Rasi, S.; De Paoli, L.; Spina, V.; Gattei, V.; Capello, D.; et al. The Prognostic Value of TP53 Mutations in Chronic Lymphocytic Leukemia Is Independent of Del17p13: Implications for Overall Survival and Chemorefractoriness. Clin. Cancer Res. 2009, 15, 995-1004. [CrossRef]

101. Rossi, D.; Spina, V.; Gaidano, G. Biology and treatment of Richter syndrome. Blood 2018, 131, 2761-2772. [CrossRef]

102. Condoluci, A.; Di Bergamo, L.T.; Langerbeins, P.; Hoechstetter, M.A.; Herling, C.D.; De Paoli, L.; Delgado, J.; Rabe, K.G.; Gentile, M.; Doubek, M.; et al. International prognostic score for asymptomatic early-stage chronic lymphocytic leukemia. Blood 2020, 135, 1859-1869. [CrossRef]

103. Hallek, M.; Shanafelt, T.D.; Eichhorst, B. Chronic lymphocytic leukaemia. Lancet 2018, 391, 1524-1537. [CrossRef]

104. Malcikova, J.; Tausch, E.; Rossi, D.; Sutton, L.A.; Soussi, T.; Zenz, T.; Kater, A.P.; Niemann, C.U.; Gonzalez, D.; Davi, F.; et al. ERIC recommendations for TP53 mutation analysis in chronic lymphocytic leukemia-Update on methodological approaches and results interpretation. Leukemia 2018, 32, 1070-1080. [CrossRef] [PubMed]

105. Zatloukalová, P.; Galoczová, M.; Vojtěšek, B. Prima-1 and APR-246 in Cancer Therapy. Klin. Onkol. 2018, 31, 71-76. [CrossRef] [PubMed]

106. Duffy, M.J.; Synnott, N.C.; O'Grady, S.; Crown, J. Targeting p53 for the treatment of cancer. Semin. Cancer Biol. 2020. [CrossRef]

107. Teras, L.R.; DeSantis, C.E.; Cerhan, J.R.; Morton, L.M.; Jemal, A.; Flowers, C.R. 2016 US lymphoid malignancy statistics by World Health Organization subtypes. CA A Cancer J. Clin. 2016, 66, 443-459. [CrossRef]

108. Moia, R.; Favini, C.; Ferri, V.; Forestieri, G.; Di Bergamo, L.T.; Schipani, M.; Sagiraju, S.; Andorno, A.; Rasi, S.; Adhinaveni, R.; et al. Multiregional sequencing and circulating tumour DNA analysis provide complementary approaches for comprehensive disease profiling of small lymphocytic lymphoma. Br. J. Haematol. 2021, 195, 108-112. [CrossRef]

109. Burger, J.A.; Gribben, J.G. The microenvironment in chronic lymphocytic leukemia (CLL) and other B cell malignancies: Insight into disease biology and new targeted therapies. Semin. Cancer Biol. 2014, 24, 71-81. [CrossRef]

110. Patriarca, A.; Gaidano, G. Investigational drugs for the treatment of diffuse large B-cell lymphoma. Expert Opin. Investig. Drugs 2020, 30, 25-38. [CrossRef] 